\title{
Evaluation of shear bond strength of two resin-based composites and glass ionomer cement to pure tricalcium silicate-based cement (Biodentine ${ }^{\circledR}$ )
}

\author{
Kenan CANTEKIN, Serap AVCi
}

Department of Pediatric Dentistry, Faculty of Dentistry, Erciyes University, Kayseri, Turkey.

Corresponding address: Kenan Cantekın - Erciyes Universitesi Dishekimligi Fakultesi Çocuk Dishekimligi Anabilim Dali, 38039, Melikgazi, Kayseri, Turkey - Phone: +90 (352) 2076666 - 29250 - Fax: +90 3524380657 - e-mail: k_cantekin@hotmail.com

Submitted: December 06, 2013 - Modification: April 23, 2014 - Accepted: April 28, 2014

\section{ABSTRACT}

\begin{abstract}
$\mathrm{O}$ bjectives: Tricalcium silicate is the major constituent phase in mineral trioxide aggregate (MTA). It is thus postulated that pure tricalcium silicate can replace the Portland cement component of MTA. The aim of this study was to evaluate bond strength of methacrylatebased (MB) composites, silorane-based (SB) composites, and glass ionomer cement (GIC) to Biodentine ${ }^{\circledR}$ and mineral trioxide aggregate (MTA). Material and Methods: Acrylic blocks $(\mathrm{n}=90,2 \mathrm{~mm}$ high, $5 \mathrm{~mm}$ diameter central hole) were prepared. In 45 of the samples, the holes were fully filled with Biodentine ${ }^{\circledR}$ and in the other 45 samples, the holes were fully filled with MTA. The Biodentine ${ }^{\circledR}$ and the MTA samples were randomly divided into 3 subgroups of 15 specimens each: Group-1: MB composite; Group-2: SB composite; and Group-3: GIC. For the shear bond strength (SBS) test, each block was secured in a universal testing machine. Results: The highest $(17.7 \pm 6.2 \mathrm{MPa})$ and the lowest $(5.8 \pm 3.2$ $\mathrm{MPa}$ ) bond strength values were recorded for the MB composite-Biodentine ${ }^{\circledR}$ and the GICMTA, respectively. Although the MB composite showed significantly higher bond strength to Biodentine $(17.7 \pm 6.2)$ than it did to MTA $(8.9 \pm 5.7)(p<0.001)$, the SB composite (SB and MTA $=7.4 \pm 3.3$; SB and Biodentine ${ }^{\circledR}=8.0 \pm 3,6$ ) and GIC (GIC and MTA=5.8 \pm 3.2 ; GIC and Biodentine $=6.7 \pm 2.6$ ) showed similar bond strength performance with MTA compared with Biodentine ( $p=0.73$ and $p=0.38$, respectively). Conclusions: The new pure tricalciumbased pulp capping, repair, and endodontic material showed higher shear bond scores compared to MTA when used with the MB composite.
\end{abstract}

Keywords: Silicate cement. Shear strength. Silorane resin.

\section{INTRODUCTION}

Calcium silicate-based dental material, known as mineral trioxide aggregate (MTA), was first described in the dental scientific literature in $1993^{19}$, and received US Food and Drug Administration approval for endodontic use in $1998^{21}$. Over the last decade, MTA has gained great popularity, especially in endodontic and pediatric dentistry, because it possesses improved physical and regenerative characteristics: it supports cementum regrowth ${ }^{3}$, has low solubility after setting ${ }^{11}$, can set in a wet environment, facilitates the control of bleeding, provides a strong barrier for bacterial leakage, and can induce mineralized tissue formation ${ }^{8}$. These advanced properties mean that MTA is one of the most successfully used materials in clinical procedures, especially endodontic and surgical applications, including direct pulp capping, apexification, regenerative endodontic treatment (apexogenesis), pulpotomy, and the sealing of perforations. It can also be used as a root-end filling material after root-end resection ${ }^{12,13,20,24}$.

MTA is primarily composed of tricalcium and dicalcium silicate and is not only used in the treatment of mature or immature permanent teeth, 
but also in primary teeth treatment. Moreover, it has recently been proposed as an alternative agent to formocresol for pulpotomy treatment in primary molars ${ }^{1,14,15,23}$. Several studies have investigated the success of MTA compared to formocresol, as well as other treatments such as ferric sulfate and calcium hydroxide, and it has exhibited a significantly improved clinical performance independent of the time until exfoliation of the primary molar ${ }^{1,10,14,15,23}$. Despite its unique combination of favorable properties, MTA has some critical shortcomings, namely the prolonged setting time, the high solubility during the setting time, the potential for discoloration, and difficultly in handling 4 .

Several new calcium silicate-based capping materials have recently been developed in response to the growing demand to overcome the disadvantages of MTA. Biodentine ${ }^{\circledR}$ (Septodont, Saint Maur des Fosses, France), the new highpurity, calcium silicate-based dental cement, was designed as a dentin substitute for resin composite restorations, pulp capping, and endodontic repair material. Biodentine ${ }^{\circledR}$ contains tricalcium silicate, calcium carbonate (filler), zirconium oxide (radiopacifier), and a water-based liquid composed of calcium chloride as a water-reducing agent for shorter initial and final setting times, as it also accelerates the rate of early strength development. Biodentine ${ }^{\circledR}$ has improved sealing ability, higher compressive strengths, shorter setting time (10 minutes), greater biocompatibility, bioactivity and biomineralization properties than $\mathrm{MTA}^{17,18}$. Moreover, Biodentine ${ }^{\circledR}$ shows improved antibacterial properties compared to MTA, as well as a low cytotoxic effect ${ }^{22}$.

Resin composites and glass ionomer cements (GICs) are very popular in restorative dentistry because of their esthetic qualities. They cannot be placed directly over freshly mixed MTA because they can affect its setting, and the etching and rinsing of unset MTA can dislodge the material. However, it has been claimed that the setting time of Biodentine ${ }^{\circledR}$ is 12 minutes, so the hypothesis is that resin composites and GICs can be layered over set Biodentine ${ }^{\circledR}$ after 12 minutes, which might enable single-visit procedures.

However, the strength with which restorative materials bond to Biodentine ${ }^{\circledR}$ is unclear. In this study, we evaluated the bond strength of methacrylate-based (MB) composites, silorane-

\begin{tabular}{|c|c|c|}
\hline Material & Manufacturer & Method/steps for Application \\
\hline Tricalcium-Silicate Cement & $\begin{array}{l}\text { Biodentine } ® \text { (Septodont, Saint Maur } \\
\text { des Fosses, France) }\end{array}$ & $\begin{array}{l}\text { Mixing premeasured unit dose } \\
\text { capsules in a high-speed amalgamator } \\
\text { for } 30 \mathrm{~s} .\end{array}$ \\
\hline MTA & $\begin{array}{l}\text { ProRoot MTA (Dentsply Tulsa } \\
\text { Dental,USA) }\end{array}$ & Mix powder and liquid in a 1:3 ratio. \\
\hline Methacrylate-based composite & $\begin{array}{l}\text { Aelite All Purpose Body (Bisco Inc, } \\
\text { Schamburg, IL, USA) }\end{array}$ & Light polymerize for $20 \mathrm{~s}$. \\
\hline $\begin{array}{l}\text { One-Step Plus (2-step total-etch } \\
\text { adhesive system) }\end{array}$ & $\begin{array}{l}\text { All-Bond } 2 \text { (Bisco Inc, Schamburg, IL, } \\
\text { USA) }\end{array}$ & $\begin{array}{l}\text { 1. Apply } 37.5 \% \text { phosphoric acid } \\
\text { etchant for } 15 \mathrm{~s} \text {. } \\
\text { 2. Rinse for } 10 \mathrm{~s} \text {. } \\
\text { 3. Dry for } 10 \mathrm{~s} \text {. } \\
\text { 4. Mix liquids A and B for } 5 \mathrm{~s} \text {. } \\
\text { 5. Apply adhesive for } 5 \mathrm{~s} \text {. } \\
\text { 6. Gentle air stream. } \\
\text { 7. Light polymerize for } 10 \mathrm{~s} \text {. }\end{array}$ \\
\hline Silorane-based composite & $\begin{array}{l}\text { Filtek Silorane (3M ESPE, St. Paul, } \\
\text { MN, USA) }\end{array}$ & Light polymerize for $20 \mathrm{~s}$. \\
\hline $\begin{array}{c}\text { Silorane Bond (2-step self-etching } \\
\text { primer) }\end{array}$ & $\begin{array}{l}\text { Filtek Silorane Bond ( } 3 \text { M ESPE, St. } \\
\text { Paul, MN, USA) }\end{array}$ & $\begin{array}{l}\text { 1. Dry surface. } \\
\text { 2. Apply primer. } \\
\text { 3. Gentle air stream for } 10 \mathrm{~s} \text {. } \\
\text { 4. Light polymerize for } 10 \mathrm{~s} \text {. } \\
\text { 5. Apply adhesive. } \\
\text { 6. Gentle air stream. } \\
\text { 7. Light polymerize for } 10 \mathrm{~s} \text {. }\end{array}$ \\
\hline Conventional glass ionomer cement & GC Fuji IX (GC, Tokyo, Japan) & Mix powder and liquid in a 1:3 ratio. \\
\hline
\end{tabular}

Figure 1- Manufacturer and application details of the materials used in the study 
based (SB) composites, and GIC when used with Biodentine ${ }^{\circledR}$ and MTA.

\section{MATERIAL AND METHODS}

The materials used in this study included tricalcium silicate-based cement (Biodentine ${ }^{\circledR}$, Septodont, Saint Maur des Fosses, France), white MTA (ProRoot MTA, Dentsply Tulsa Dental, Tulsa, OK, USA), MB composite resin (AELITE, Bisco, Inc., Schaumburg, IL, USA), SB composite resin (Filtek ${ }^{\mathrm{TM}}$ Silorane, 3M ESPE, St. Paul, MN, USA), and conventional GIC (GC Fuji IX, GC, Tokyo, Japan). The application steps for Biodentine ${ }^{\circledR}$ and resin composites, as well as the powder-to-liquid ratios of MTA and GICs recommended by the manufacturers, are listed in Figure 1.

\section{Specimen preparation}

Acrylic blocks $(n=90)$ with $2 \mathrm{~mm}$ high and $5 \mathrm{~mm}$ diameter central holes were prepared. In 45 of the samples, the holes were fully filled with Biodentine ${ }^{\circledR}$. In the other 45 samples, the holes were fully filled with MTA.

Biodentine ${ }^{\circledR}$ and MTA specimens were stored at $37^{\circ} \mathrm{C}$ in $100 \%$ humidity for respectively 15 minutes and 96 hours for setting.

\section{Placement of restorative materials}

After the settings, both the Biodentine ${ }^{\circledR}$ and the MTA samples were randomly divided into 3 subgroups of 15 specimens each: Group 1: Methacrylate-based (MB) composite; Group 2: Silorane-based (SB) composite; and Group 3: Glass-ionomer cement (GIC). In Groups 1 and 2,

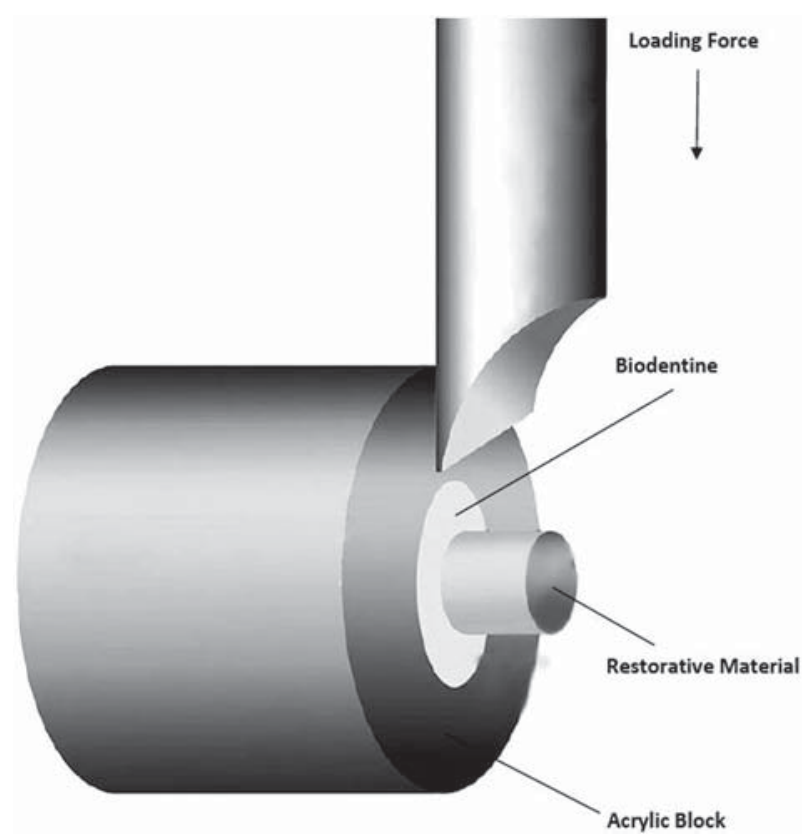

Figure 2- Schematic illustration of the shear bond strength test set-up the corresponding adhesive system was applied over the Biodentine ${ }^{\circledR}$ and MTA samples according to the manufacturers' instructions, as displayed in Figure 1. Each resin composite or GIC specimen was placed at the center of the Biodentine ${ }^{\circledR}$ and the MTA surface by placing the packing materials into cylindrically shaped plastic tubes with internal diameter of 2 $\mathrm{mm}$ and height of $2 \mathrm{~mm}$. The composite specimens were cured with a light-emitting diode light cure (VALO LED, Ultradent, South Jordan, USA) with an intensity of $1,200 \mathrm{~mW} / \mathrm{cm}^{2}$ for 20 seconds. The GIC specimens were allowed to set for 10 minutes within the plastic tubes. After the polymerization or setting process, the plastic tubes were removed carefully and the specimens were stored at $37^{\circ} \mathrm{C}$ in $100 \%$ humidity for 24 hours. All the samples were prepared and tested by a single investigator (K.C.).

\section{Shear bond strength (SBS) test}

For the SBS test, each block was secured in a universal testing machine (Instron, AGS-1000kGW; Shimadzu Corp., Chiroda-Ku, Tokyo, Japan). A chisel-edge plunger was mounted onto the movable crosshead of the testing machine and positioned so that the leading edge was aimed at the Biodentine ${ }^{\circledR}$ or the MTA base/adhesive interface (Figure 2 ). The force required to remove the restorative material was measured in Newtons ( $\mathrm{N})\left(1 \mathrm{MPa}=1 \mathrm{~N} / \mathrm{mm}^{2}\right)$, and the SBS was then calculated by dividing the peak load values by the restorative material base area $\left(3.14 \mathrm{~mm}^{2}\right)$.

\section{Statistical analysis}

All calculations were processed using the Statistical Package for the Social Sciences (SPSS) statistical software, version 16 (SPSS Inc., Chicago, IL, USA). The Kolmogorov-Smirnov test was used to evaluate the normality of the data distribution. The means, minimums, maximums, and standard deviations were also calculated. The mean bond strengths of the groups were compared using oneway analysis of variance (ANOVA) and Tukey's posthoc test (honestly significant difference) was used for a two-by-two comparison $(p<0.05)$.

\section{RESULTS}

Table 1 shows the descriptive statistics of shear bond strength for each group. The ANOVA that compared the experimental groups revealed the presence of significant differences among the groups $(p<0.001)$. The highest $(17.7 \mathrm{MPa})$ and the lowest (5.3 $\mathrm{MPa}$ ) bond strength values were recorded for the $\mathrm{MB}$ composite-Biodentine ${ }^{\circledR}$ and the GIC-MTA, respectively.

Although the MB composite showed significantly higher bond strength to Biodentine ${ }^{\circledR}$ than it did to MTA $(p<0.001)$, the SB composite and GIC showed 
Table 1- Shear bond strength values of restorative materials to Biodentine ${ }^{\circledR}$ and conventional mineral trioxide aggregate (MTA)

\begin{tabular}{cccccc}
\hline $\begin{array}{c}\text { Restorative } \\
\text { materials }\end{array}$ & N & Mean & $\mathbf{N}$ & Mean & Papping Materials \\
\hline MB composite & 15 & $17.7 \pm 6.2$ & 15 & $8.9 \pm 5.7$ & $<0.001^{*}$ \\
SB composite & 15 & $8.0 \pm 3.6$ & 15 & $7.4 \pm 3.3$ & 0.73 \\
GIC & 15 & $6.7 \pm 2.6$ & 15 & $5.8 \pm 3.2$ & 0.35 \\
Total & 45 & $10.8 \pm 6.6$ & 45 & $7.2 \pm 4.4$ & $0.003^{*}$ \\
\hline
\end{tabular}

*There was a statistically significant difference

similar bond strength performance with MTA compared with Biodentine ${ }^{\circledR}(p=0.73$ and $p=0.38$, respectively). The post-hoc test indicated that the MB composite showed significantly higher bond strength to Biodentine ${ }^{\circledR}$ and MTA $(p<0.001)$ than the other restorative materials. The SB composite and the GIC specimen, however, demonstrated a similar SBS $(p=0.17)$.

\section{DISCUSSION}

We designed the present study to evaluate and compare the shear bond strength (SBS) of MB composites, SB composites, and conventional GIC materials when used with Biodentine ${ }^{\circledR}$ and MTA. Several studies have reported obtaining optimal SBS with total etch adhesive systems ${ }^{5,6,16}$ when comparing the SBS of various adhesive systems used with MTA for different time intervals, as phosphoric acid has been shown to produce deeper and more retentive micro porosity than even the strongest self-etching adhesive. It has also been demonstrated that restorative procedures should be postponed for at least 72 to 96 hours $7,16,25$ after mixing MTA to allow the material to achieve its optimum physical properties. The purpose of the present study was not to assess the waiting times with regard to the SBS of restorative materials when used with MTA, since this has already been evaluated in numerous studies, as previously mentioned. Therefore, the MTA and Biodentine ${ }^{\circledR}$ subjects remained untouched for 96 hours and 15 minutes, respectively, after application, and we applied the MB composite with a total etch adhesive system before the placement of the composite resin restorations.

The strength of the bond between the restorative material and the enamel/dentin, as well as between the restorative material and the cavity liner, is one of the most critical factors for quality dental filling treatment. A bond strength ranging from $17 \mathrm{MPa}$ to $20 \mathrm{MPa}$ may be required to sufficiently resist contraction forces and produce gap-free restoration margins $^{2,5,9}$. Our findings demonstrated that the MB composite with Biodentine ${ }^{\circledR}$ showed the highest bond strength, and only this group reached an optimal shear bond, with a mean 17.7 MPa SBS value (Table 1 ). Biodentine ${ }^{\circledR}$ significantly increased the SBS value for the MS composite compared to MTA, and it reached the optimal SBS value. With regard to the $M B$ composite, the difference in the SBS value for Biodentine ${ }^{\circledR}$ and MTA was statistically significant $(p<0.001)$. The results showed that although the SBS values of the SB composite and GIC that were used with Biodentine ${ }^{\circledR}$ (8.0 $\mathrm{MPa}$ and 6.7 $\mathrm{MPa}$, respectively) were higher than their SBS when bonded to MTA (7.4 MPa and 5.3 $\mathrm{MPa}$, respectively), the differences between these subgroups were not statistically significant $(p<0.05)$. Several studies have evaluated the effects of the bond strength of MB composite resins and GIC when bonding to MTA, and have indicated that MB composite resins showed low SBS values, ranging from $5.06 \mathrm{MPa}$ to $13.45 \mathrm{MPa}, 4$ to 48 hours after mixing the MTA, and high SBS values, ranging from 14.44 MPa to $18.25 \mathrm{MPa}, 72$ to 96 hours after mixing the MTA. SBS values of bonding of GIC to MTA were reported as $8.85 \mathrm{MPa}$ and $9.16 \mathrm{MPa}$ at 45 minutes and 72 hours, respectively, after mixing the $\mathrm{MTA}^{26}$.

However, a resin system based on the ringopening polymerization of silorane molecules containing both hydrophobic siloxane and low shrinkage oxirane, rather than the free radical polymerization of dimethacrylate (DMA) monomers of a methacrylate-based composite, has recently been developed. The ring mechanism of the silorane composite allows a reduction in polymerization shrinkage and, according to some studies, siloranes also decrease polymerization stress ${ }^{29,30}$. However, the shear bond of silorane-based materials when bonded to Biodentine ${ }^{\circledR}$ or MTA is unclear. The mean SBS value of the SB composite and the conventional GIC used in the present study did not fall within the clinically acceptable range. Although the bond strength of the silorane composite $(7.7 \mathrm{MPa})$ was greater than the bond strength of conventional GIC (6.0 MPa), the difference was not statistically 
significant $(p<0.05)$. However, the SB composite has several advantages with regard to polymerization shrinkage and stress; these were lower than when the MB composite was used $(p<0.001)$.

On the basis of the methodology, the limitations of this study were (i) we based the SBS evaluation on only one setting time, and the adhesive systems have different setting times, and we did not consider alternative bonding systems, and (ii) the study was designed as an in vitro evaluation. Future studies should investigate the effects of different bonding protocols on the surface and structural characteristics of Biodentine ${ }^{\circledR}$ to provide an insight into the adhesive mechanisms of the different bonding systems and Biodentine ${ }^{\circledR}$ under strict laboratory conditions and in larger cohorts.

\section{CONCLUSIONS}

Within the limitations of this study, the new pure tricalcium-based pulp capping, repair and endodontic material showed clinically acceptable and higher shear bond scores compared to MTA when used with the MB composite. However, the SB composite and GIC bonded to Biodentine ${ }^{\circledR}$ and MTA at a fairly low strength.

\section{CONFLICT OF INTEREST}

The authors declare that they have no conflict of interest.

\section{REFERENCES}

1- Aeinehchi M, Dadvand S, Fayazi S, Bayat-Movahed S. Randomized controlled trial of mineral trioxide aggregate and formocresol for pulpotomy in primary molar teeth. Int Endod J. 2007;40:261-7.

2- Al-Sarheed MA. Evaluation of shear bond strength and SEM observation of all-in-one self-etching primer used for bonding of fissure sealants. J Contemp Dent Pract. 2006;7:9-16.

3- Alhadainy HA. Root perforations. A review of literature. Oral Surg Oral Med Oral Pathol. 1994;78:368-74.

4- Antunes Bortoluzzi E, Juárez Broon N, Antonio Hungaro Duarte M, Oliveira Demarchi AC, Monteiro Bramante C. The use of a setting accelerator and its effect on $\mathrm{pH}$ and calcium ion release of mineral trioxide aggregate and white Portland cement. J Endod. 2006;32:1194-7.

5- Atabek D, Sillelioğlu H, Olmez A. Bond strength of adhesive systems to mineral trioxide aggregate with different time intervals. J Endod. 2012;38:1288-92.

6- Bayrak S, Tunç ES, Saroğlu I, Eğilmez T. Shear bond strengths of different adhesive systems to white mineral trioxide aggregate. Dent Mater J. 2009;28:62-7.
7- Bodanezi A, Carvalho N, Silva D, Bernardineli N, Bramante CM, Garcia RB, et al. Immediate and delayed solubility of mineral trioxide aggregate and Portland cement. J Appl Oral Sci. 2008;16:127-31.

8- Camilleri J. Hydration mechanisms of mineral trioxide aggregate. Int Endod J. 2007;40:462-70.

9- Davidson $\mathrm{CL}$, de Gee AJ, Feilzer A. The competition between the composite-dentin bond strength and the polymerization contraction stress. J Dent Res. 1984;63:1396-9.

10- Farsi N, Alamoudi N, Balto K, Mushayt A. Success of mineral trioxide aggregate in pulpotomized primary molars. J Clin Pediatr Dent. 2005;29:307-11.

11- Fridland M, Rosado R. MTA solubility: a long term study. J Endod. 2005;31:376-9.

12- Hargreaves KM, Diogenes A, Teixeira FB. Treatment options: biological basis of regenerative endodontic procedures. J Endod. 2013;39:S30-43.

13- Hargreaves KM, Diogenes A, Teixeira FB. Treatment options: biological basis of regenerative endodontic procedures. Pediatr Dent. 2013;35:129-40.

14- Holan G, Eidelman E, Fuks AB. Long-term evaluation of pulpotomy in primary molars using mineral trioxide aggregate or formocresol. Pediatr Dent. 2005;27:129-36.

15- Hutcheson C, Seale NS, McWhorter A, Kerins C, Wright J. Multi-surface composite vs stainless steel crown restorations after mineral trioxide aggregate pulpotomy: a randomized controlled trial. Pediatr Dent. 2012;34:460-7

16- Kayahan MB, Nekoofar MH, Kazandağ M, Canpolat C, Malkondu $\mathrm{O}$, Kaptan $\mathrm{F}$, et al. Effect of acid-etching procedure on selected physical properties of mineral trioxide aggregate. Int Endod J. 2009;42:1004-14.

17- Koubi G, Colon P, Franquin JC, Hartmann A, Richard G, Faure $\mathrm{MO}$, et al. Clinical evaluation of the performance and safety of a new dentine substitute, Biodentine, in the restoration of posterior teeth - a prospective study. Clin Oral Investig. 2012;17:243-9

18- Laurent P, Camps J, About I. Biodentine(TM) induces TGFbeta1 release from human pulp cells and early dental pulp mineralization. Int Endod J. 2012;45:439-48.

19- Lee SJ, Monsef M, Torabinejad M. Sealing ability of a mineral trioxide aggregate for repair of lateral root perforations. J Endod. 1993;19:541-4.

20- Paryani K, Kim SG. Regenerative endodontic treatment of permanent teeth after completion of root development: a report of 2 cases. J Endod. 2013;39:929-34.

21- Schmitt D, Lee J, Bogen G. Multifaceted use of ProRoot MTA root canal repair material. Pediatr Dent. 2001;23:326-30.

22- Shayegan A, Jurysta C, Atash R, Petein M, Abbeele AV. Biodentine used as a pulp-capping agent in primary pig teeth. Pediatr Dent. 2012;34:e202-8.

23- Subramaniam P, Konde S, Mathew S, Sugnani S. Mineral trioxide aggregate as pulp capping agent for primary teeth pulpotomy: 2 year follow up study. J Clin Pediatr Dent. 2009;33:311-4.

24- Torabinejad M, Chivian N. Clinical applications of mineral trioxide aggregate. J Endod. 1999;25:197-205.

25- Vanderweele RA, Schwartz SA, Beeson TJ. Effect of blood contamination on retention characteristics of MTA when mixed with different liquids. J Endod. 2006;32:421-4.

26- Yesilyurt C, Yildirim T, Tasdemir T, Kusgoz A. Shear bond strength of conventional glass ionomer cements bound to mineral trioxide aggregate. J Endod. 2009;35:1381-3. 